\title{
THE CONCEPT OF 'NATURE' IN ARISTOTLE, AVICENNA AND AVERROES*
}

\author{
Catarina Belo** \\ cbelo@aucegypt.edu
}

RESUMO $O$ presente artigo trata da 'natureza' enquanto objeto da física, ou da ciência natural, tal como descrita por Aristóteles na "Física". Também trata das definições da natureza, especificamente a natureza física, fornecidas por Avicena (m. 1037) e Averróis (m. 1198) nos seus comentários à "Física" de Aristóteles. Avicena e Averróis partilham da conceção da natureza de Aristóteles enquanto princípio de movimento e repouso. Enquanto para Aristóteles o objeto da física parece ser a natureza, ou aquilo que existe por natureza, Avicena defende que é o corpo natural, e Averróis afirma que o objeto da fisica, ou ciência natural, consiste nas coisas naturais, apresentando uma ênfase algo diferente.

Palavras-chave Natureza, física, substância, Aristóteles, Avicena, Averróis.

ABSTRACT This study is concerned with 'nature' specifically as the subject-matter of physics, or natural science, as described by Aristotle in his "Physics". It also discusses the definitions of nature, and more specifically physical nature, provided by Avicenna (d. 1037) and Averroes (d. 1198) in their commentaries on Aristotle's "Physics". Avicenna and Averroes share Aristotle's conception of nature as a principle of motion and rest. While according to Aristotle the subject matter of physics appears to be nature,

* An earlier version of this paper was presented at the International Medieval Congress 2008, University of Leeds, United Kingdom, 7-10 July 2008. I am grateful for the comments on my paper by the other congress participants.

** Associate Professor of Philosophy, Department of Philosophy - The American University in Cairo. Artigo recebido em 24/05/2014 e aprovado em 13/08/2014. 
or what exists by nature, Avicenna believes that it is the natural body, and Averroes holds that the subject matter of physics or natural science consists in the natural things, in what constitutes a slight shift in focus.

Keywords Nature, physics, substance, Aristotle, Avicenna, Averroes.

The definition of nature, and more specifically physical nature, is discussed by Avicenna (d. 1037) and Averroes (d. 1198) in their commentaries on Aristotle's "Physics", which sets the tone on this topic for the remainder of the classical period and until the start of the Renaissance. This study is concerned with 'nature' specifically as the subject-matter of physics, or natural science, as described by Aristotle in his "Physics".

Avicenna's gloss on this work is to be found in his magnus opus, "alShifā" (which has been translated into English as "The Healing" and "The Cure"), an encyclopaedia of the sciences, embracing the three main medieval disciplines, logic, physics, and metaphysics. This work is not a literal commentary on Aristotle's corpus, even though Avicenna does manage to touch on all the main points which Aristotle treats.

Averroes offers a more literal type of commentary on Aristotle's works, especially in his long commentaries, which are considered to have been composed after his short and middle commentaries. Therefore the "Long Commentary on the Physics" will serve as my basis for examining Averroes' understanding of nature.

Before examining Avicenna's and Averroes' views, it is appropriate to start with Aristotle and his definition of the subject-matter of physics, namely, nature.

\section{Aristotle on nature}

Aristotle defines nature (physis) and natural processes in the "Physics", especially in the first two books of this work. In book one, while examining the theories of the Pre-Socratic philosophers, his predecessors - such as Anaxagoras, Anaximander, Democritus, Empedocles, and especially Melissus and Parmenides - and their theories about the world, Aristotle introduces his understanding of nature, which he associates with motion, in the sense that all, or some, natural things are in motion. ${ }^{1}$ For that reason he asserts, against 
Parmenides and Melissus, that "to investigate whether what exists is one and motionless is not a contribution to the science of nature" (Aristotle, "Physics", $\left.184^{\mathrm{b}} 25-185^{\mathrm{a}} 1\right) .^{2}$ Moreover, coming to be and passing away are characteristics of natural substances, and natural science takes into account change and the elements of change in the natural world, namely form (such as 'human'), matter (such as 'flesh'), and privation (the absence of a particular form). He mentions the four elements, earth, water, air and fire, as parts of the natural world. Nature can also refer to natural essences or substances, and be related to one particular cause, the material cause or the matter of the substance in question. The first book of the "Physics" explains what belongs to natural science and what does not.

In the second book of the "Physics", Aristotle defines nature more specifically, and he contraposes it to art. Among the natural substances are plants and animals, and also simple bodies, such as the elements.

Nature is a principle of innate motion and rest in substances, which move or become stationary by themselves and not through an external cause or accidentally. Hence nature is an inner, not external, principle of motion and rest in substances, and things are said to be according to nature if they possess this inner principle. ${ }^{3}$ Natural motion can take on different forms or directions. Nature controls and explains the actions of a given substance. Nature can act as the substance's efficient cause or agent, especially in the case of motion, but also change. ${ }^{4}$ The natural form is perishable and is studied by physics, the science of nature.

More specifically, examples of natural substances are for instance an animal, which can move or rest; also the celestial bodies, which move by themselves, as well as plants, which are restricted in their movements, since they can only move upwards as they grow. According to Aristotle the concept of motion embraces other forms that would not be immediately intuitive to the modern reader. In addition to motion in space, change and growth also constitute motion. ${ }^{5}$ Aristotle also defines that which occurs by nature, such as fire moving upwards or a stone downwards. These are natural movements.

Concerning the difference between nature and art, Aristotle contrasts natural objects to artificial objects, which are the product of an art or craft. Thus a table or a stool do not have in themselves the power to move; they

\footnotetext{
2 In J. Barnes' translation, p. 316.

Ibidem, $192^{\mathrm{b}} 20-23$.

4 According to S. Waterlow (1982, p. 27), "Aristotle holds a thing's nature to be an inner principle of change".

5 According to F. J. E. Woodbridge (1965, p. 150), motion includes: "1. From what can be to what is. 2. Getting larger or smaller. 3. Coming to be and passing away. 4. From one place to another".
} 
must be moved by other, external, agents. In addition, artificial objects, unlike natural bodies, cannot produce another like itself; they have no reproductive capacity. ${ }^{6}$

After distinguishing nature from art, Aristotle goes on to ascertain in what exactly nature consists. That is to say, natural substances are composed of matter and form. In which of these does nature consist? The Stagirite takes pains to counter the argument of Antiphon to the effect that since matter, unlike form, does not change, and appears to be wholly stable and durable, it has a greater claim to the designation of nature than form does.

Some identify the nature or substance of a natural object with that immediate constituent of it which taken by itself is without arrangement, e.g. the wood is the nature of the bed, and the bronze the nature of the statue.

As an indication of this Antiphon points out that if you planted a bed and the rotting wood acquired the power of sending up a shoot, it would not be a bed that would come up, but wood which shows that the arrangement in accordance with rules of the art is merely an accidental attribute, whereas the substance is the other, which, further, persists continuously through the process. (Aristotle, "Physics", 193a9-17) ${ }^{7}$

However Aristotle does not accept this inference, stating in no uncertain terms the primacy of form or shape as a constituent of natural substances. Since form (for instance, the shape or definition of an individual substance) is the active principle that actualises the compound, and matter (for instance, wood) is the passive element that receives the form, nature is more readily identifiable with form than with matter. Even in natural substances (unlike a bed), the form is that which characterises the substance in question.

Nature is also an end, or a goal. Thus nature is identified with the four causes (agent, matter, end, and form), which explain change, as well as coming to be and passing away. It becomes apparent that some of the elements of this science overlap with metaphysics, such as the four causes and the nature of substance, but Aristotle studies these as they are subject to motion and change, in the natural world.

\section{Avicenna on nature}

In the first chapter of the "Physics" of "The Healing" ("al-Shifā"), Avicenna stipulates that the subject matter of physics is "the sensible body

6 F. J. E. Woodbridge (1965, p. 53) adds: "Nature is, or natural objects are, that which itself contains the determination of what it is to be, while art is, or artificial objects are, that which has this determination elsewhere. In the plant the determination is in the plant; in the house, it is in the builder".

7 In J. Barnes' translation, pp. 329-330. 
insofar as it is subject to change" (Avicenna, "The Physics of the Healing", p. 3), and this body has three dimensions. He explains the conditions of knowledge in relation to species and genus, and remarks that the universal is known to the intellect as something simple, while the particular composite object is closer to the senses. ${ }^{8}$ Avicenna's understanding of the subject-matter of physics differs from Aristotle's, given that the latter focuses on nature as an organic process, and Avicenna focuses on natural bodies. As such, chapters three and four of Avicenna's "Physics" are devoted to the explanation of the natural body and its principles, which are the matter and the form of the particular body, and considers the form of corporeality in itself. The matter of the body can also be called material, subject, component and element. ${ }^{9}$ In addition to these two elements, he mentions the agent and the end:

The body also has additional principles: and agent and an end. The agent is that which impresses the form belonging to bodies into their matter, thereby making the matter subsist through the form and from [the matter and form] making the composite subsist, where [the composite] acts by virtue of its form and is acted upon by virtue of its matter. The end is that for the sake of which these forms are impressed into the matters. (Avicenna, "The Physics of the Healing", p. 16)

Avicenna argues that these four principles are not specific to physics, and thus their existence is proved in metaphysics. Since change is also an important element which is observed in natural substances, he brings up another important factor in explaining change in natural substances, namely privation, or the absence of a particular form. Without it, a form would not be able to leave a certain matter. For example, one would not be able to tan if the lighter complexion did not leave the body.

Thus form and matter, the inseparable principles of the body, and privation are essential to account for change of that body; more specifically, the form explains the generation of a substance, and the privation (when the substantial form leaves the compound) its corruption. ${ }^{10}$ This discussion continues in chapter three, and in chapter four Avicenna analyses the views held by Parmenides and Melissus, before turning to the concept of nature in chapter five.

He distinguishes motion that comes from the natural substance itself, and motion which is caused by an external object or factor: 
Certain actions or movements occur in the bodies that are immediately present to us. Now, on the one hand, we find that some of those actions and movements proceed from certain external causes that make their occurrence in [the bodies] necessary, as, for example, water's being heated and a stone's rising. On the other hand, we find that other actions and movements proceed from [the bodies] owing to [the bodies] themselves in such a way that they are not traced back to some foreign cause - as, for example, when we heat water and then leave it alone, it cools through its own nature; and when we raise the stone and then leave it alone, it falls through its nature. (Avicenna, "The Physics of the Healing", p. 37) ${ }^{11}$

His concept of nature as something entailing order and regularity is apparent from the distinction between nature and accidental motion. According to Avicenna certain natural actions always obtain if there is no obstacle. A stone falls downwards if it encounters no obstacle. As he mentions later in the "Physics", in an example borrowed from Aristotle, if it breaks someone's head in the process, this is accidental, because it is not in the nature of the stone to produce this effect always of itself. Moreover, a person, for instance, who is stationary on a boat that moves is said to move accidentally.

Avicenna identifies nature, which is a certain power, with an inborn quality of certain substances to move automatically, stating also that the four elements have their own specific qualities and natures which determine their actions. Water is cold and earth heavy. He identifies nature specifically with the movement or natural tendency of natural elements and natural substances such as a stone, although it can also extend to plants and animals. However, it excludes volition, or voluntary actions, so much so that Avicenna adds that: "sometimes nature is applied to everything from which its action proceeds without deliberation or choice, so that the spider [may be said] to weave by nature; and the same holds for similar animals. The nature by which natural bodies are natural and that we intend to examine here, however, is nature in the first sense", namely, as "a power that brings about motion and change and from which the action proceeds according to a single course, without volition" (Avicenna, "The Physics of the Healing", p. 39). This includes the movements of the celestial spheres, or the movement of plants when they grow and the movements of animals (so excluding the celestial, the vegetative and the animal soul respectively). Thus natural motions are to be distinguished from voluntary and accidental motions and processes. However in nature one may find natural agents that are also voluntary and those that are not. Some natural actions involve knowledge and deliberation while others do not. However, 
strictly speaking, an action issuing from a deliberate resolution is voluntary rather than natural. ${ }^{12}$

Nature is, as we have seen, an inner principle of motion: "nature has been defined as the first principle of motion and rest in that to which it belongs essentially rather than accidentally" (Avicenna, "The Physics of the Healing", p. 40).

Nature, for Avicenna as for Aristotle, is a certain cause, as producing motion by itself, and this can happen according to the various categories, such as quantity (for instance, an increase in volume), quality (if water cools down after being heated), place (when fire moves upwards), or substance (if it changes its form). ${ }^{13}$

Nature can be identified with the form, as in the case of the elements, or with the origin of movement or change of some substance. Avicenna distinguishes three main meanings of nature: (1) as principle of change and motion, (2) as that which makes the substance subsist, and finally (3) the being of something. ${ }^{14}$

Moreover, as we have seen, he recalls Aristotle's broad conception of motion, to include changes in quality, place, and quantity. Natural motion must also be distinguished from forced motion. Avicenna does not accept the argument, developed after Aristotle, that nature in itself does not produce motion but something in her does. He finds this a superfluous addition to Aristotle's theory. ${ }^{15}$

Avicenna further highlights the Aristotelian theme of the priority of form over matter, in chapter six. He concurs with Aristotle on the fact that form is worthier of being called the nature of something than the material element is.

What is the relation of nature to form and matter? Nature is a principle of motion, while form is that which determines the essence of a thing and matter bears its essence or form. How is it that the nature is not to be identified simply with the form? This is sometimes the case, namely in simple substances, such as the four elements.

When form and nature coincide, nature means the actions and motions proceeding from a nature, whereas the subsistence of something is due to the form:

In some cases, the nature of the thing is just its form, whereas in others it is not. In the case of the simples [that is, the elements], the nature is the very form itself, for

12 Avicenna, "The Physics of the Healing", p. 40.

13 Ibidem, p. 44.

14 Ibidem, p. 47.

15 Ibidem, p. 43. 
water's nature is [for example] the very essence by which it is water. Be that as it may, it is a nature only when considered in one way, whereas it is a form when considered in another. So when it is related to the motions and actions that proceed from it, it is called nature; whereas, when it is related to its bringing about the subsistence of the species water, and if the effects and motions that proceed from it are not taken into account, it is then called form. (Avicenna, "The Physics of the Healing", p. 45)

As we have seen, Avicenna argues that nature can be defined in many ways, but in three ways primarily. These are nature as principle of motion and rest by itself, but also "as that by which the substance of anything subsists" (that which makes the substance subsist), and also "the very being of anything" (Avicenna, "The Physics of the Healing", p. 47).

With regard to that which makes something subsist, philosophers traditionally differed, some attributing the principle of subsistence to form, others to matter.

He addresses the issue of those who claim that matter, not form, constitutes the nature of a substance. Mentioning Antiphon's argument, discussed by Aristotle, Avicenna claims that Antiphon confused form with accident, in believing that the material, as that which remains in a substance, makes it existent, while the form comes and goes. According to Avicenna, however, form designates the essence of something, while an accident is a changeable quality that inheres in the matter of the substance. While forms can change, the substantial form (for instance, table) is what provides existence, even if accidents may vary, such as the particular colour. The material cause only provides the potential for existence, and form provides the actual existence, by providing a substance with its specific existence. While a wooden bed decomposes and may produce branches and grow, according to the example adduced by Antiphon to support the view that matter provides existence, even woodiness, according to Avicenna, is a form, rather than matter.

Thus, the perfecting form is also called nature, both in simple and composite (material) bodies, but more clearly in the case of simple bodies, which are devoid of matter. ${ }^{16}$

Avicenna also dwells on the different terms related to 'nature', such as "natural, what has a nature, what is by nature, what is naturally, and what follows the natural course" (Avicenna, "The Physics of the Healing", p. 50), and all of them refer to the definition of nature, and a certain principle of autonomy. 
He mentions his famous conception of nature in the sense of essence, as that which is neither universal not particular, but becomes universal if applied to several similar individuals, and particular if applied to or predicated of a single individual. This concept would later be taken up by Duns Scotus, who followed Avicenna's views on other matters. Hence nature does not mean primarily something universal or particular.

There may be a difference between nature as said of universals and particulars. For instance, death is a necessary end. It runs counter to the particular nature of a body, since it is not in its interests and destroys it, but it accords with and maintains the universal nature. Avicenna here claims that without death there would be no space for further individuals in the universe. This is a theme that is tied up with his view of providence, which he also refers to as the 'universal order'. According to Avicenna it is not possible to understand providence if one only takes account of individuals in isolation. The universal order in nature is a favourite Avicennan theme which he introduces in his treatment of nature. ${ }^{17}$

Another question broached by Aristotle, and analysed by Avicenna, is the method to prove the existence of nature. It is important to note that nature is a cause, as we have seen, and the natural body is the subject matter of the discipline of physics, according to Avicenna. He holds that a science cannot prove its own subject matter, for this would constitute a vicious circle. Thus the existence of the subject matter of a science must be proved by another science, as established by Aristotle in the "Posterior Analytics". It is obvious that each moved thing has a mover, and certain things have this mover in themselves. However, if a proof is required, it belongs in the first philosophy, that is, metaphysics. This point is disputed by Averroes, as we shall see later.

\section{Averroes on nature}

In his "Long Commentary on the Physics" Averroes also analyses the main points regarding the concept of nature as expounded by Aristotle and Avicenna. Nature is a principle of motion and of change in natural substances. This motion or change can occur along several categories, such as quality and quantity or place.

He affirms that all natural things have principles, causes and elements, and are known through these causes and elements. ${ }^{18}$ 
Averroes also reaffirms the Aristotelian principle that each moved thing has a mover, but natural things move of themselves while artificial things have an external mover. He believes, like Aristotle, that each natural substance has three principles, namely, form, subject and privation, although nature is especially associated with the form. Moreover, nature is a kind of cause, different from will and chance. ${ }^{19}$

Unlike artificial things, natural things have in themselves a principle of change and rest and they are called natural according to this principle, in inanimate (such as the elements) and animate substances. This principle includes such changes as growth in plants, alteration, generation and corruption in natural substances; it also includes change in quality in composite things, for instance according to matter, if it is a simple thing, and according to form, if it is a composite thing. ${ }^{20} \mathrm{He}$ remarks that a simple body does not change or is generated by itself, but it changes in place. The principle of alteration is within composite things, as in generation and corruption.

He addresses an important issue regarding change in place. Why do we not say that artificial things move of themselves (for example, a statue made of marble) whereas, for instance, a stone moves of itself to regain its natural place (e.g., if thrown upwards, it comes down of itself)? Averroes states that artificial things only accidentally move of themselves, as they do not have in themselves a principle of motion and rest; this only happens in so far as they are made of a natural substance. ${ }^{21}$

He defines nature as "a principle and cause through which that changes and rests in which it is, primarily and by itself, and not by accident" (Averroes, "Long Commentary on the Physics", 49B, my translation). Nature is a selfevident principle and it is one of the principles of physics.

$\mathrm{He}$ also considers nature as matter and form, and states, like Aristotle, that form is worthier of being called nature than matter, as we have seen, for the latter is passive while the former is active. Averroes explains various aspects pertaining to the form, claiming that, according to Alexander of Aphrodisias, those who claimed that matter constitutes the nature of things did not know the form. However, since it is the form that gives anything its name, it also constitutes its nature. Averroes then takes this reflection on form as a starting point to criticise and reject the Platonic idea of separate forms. Form is separate from matter only according to the definition. Otherwise 
form is always found together with matter. Avicenna too rejects the theory of separate forms, as appears from the "Metaphysics" of "The Healing". Yet Averroes does not think he goes far enough in the rejection of separate forms. The notion, for instance, that the Active Intellect (the last emanated intellect in the Neoplatonic schema) is the giver of forms, with the assumption that those forms and universals inhere in it, is a form of Platonism, in Averroes' estimation, for the form is really never separate from matter or a subject of inherence.

This takes us to another common criticism that Averroes levels at Avicenna. The latter affirms that the subject matter of physics must be proved in the science of metaphysics or first philosophy, although the essence of nature can be known and discussed in physics or natural philosophy. Nevertheless Averroes disagrees with Avicenna's entire approach to physics. ${ }^{22}$ According to him, Avicenna believes that physics only deals with proximate matter. In reality, for Averroes, it also deals with prime matter, which is assumed to underlie the four elements, the first visible form of matter. Indeed, Aristotle claims that both prime matter and the prime mover are proved in physics, as Averroes claims, through a natural sign. The existence of the Prime Mover, or God, is proved in the "Physics" (book 8), as stated by both Aristotle and Averroes. The latter believes that the goal of this science is to know "the causes of sensible species, and the causes of the accidents which exist in them", and the subject matter of this science is

the things that are known by the senses, which change of themselves, and have in themselves the principle of motion and rest.

The goal of this book is to know the causes of all natural things, namely matter, form, agent, and end. (Averroes, "Long Commentary on the Physics", $1 \mathrm{~K})^{23}$

For his part Avicenna does not think that such a worthy subject as God can be dealt with in physics; rather the existence of God should be demonstrated in metaphysics. This brings about Averroes' accusation in the "Physics", that Avicenna in reality uses the same method to prove God's existence as the Muslim theologians. Thus Avicenna's methods are not demonstratively correct, but stand halfway between the Peripatetic method and the theological method. 


\section{Conclusion}

In the foregoing it appears that Avicenna and Averroes share Aristotle's conception of nature as the principle of motion and rest. While according to Aristotle the subject matter of physics appears to be nature, or what exists by nature, Avicenna believes that it is the natural body, and Averroes holds that the subject matter of physics or natural science consists in the natural things, in what constitutes a slight shift in focus.

In discussing nature Avicenna and Averroes introduce aspects of their own philosophies, as we have seen. Avicenna expounds his concept of providence and reiterates his view that the proof of God's existence belongs in metaphysics. Matter, as a purely abstract subject that is not really to be found in nature, must also be dealt with in metaphysics.

Averroes, also following Aristotle, denies that form can be found separately from matter, and criticises Avicenna for a perceived departure from Aristotle's method and approach. In the main points, however, they both maintain that nature is opposed to art and that it consists in a principle of motion and rest in natural/physical substances.

\section{References}

ARISTOTLE. Physics, translated into English by Jonathan Barnes, in vol. 1 of The Complete Works of Aristotle, the Revised Oxford Translation, edited by Jonathan Barnes, 2 Vols, Bollingen Series LXXI 2, Princeton: Princeton University Press, 1984, pp. 315-446.

. "Physics". Ed. W. D. Ross, Oxford: Oxford University Press, 1998.

AVERROES. "Long Commentary on the Physics". In: Aristotelis de Physico Auditu libri octo cum Averrois Cordubensis variis in eosdem commentariis, Vol. 4 of Aristotelis Opera quae extant omnia, Venice: Venetiis apud Junctas, 1562.

AVICENNA. "The Physics of the Healing". A Parallel English-Arabic Text in Two Volumes, translated by Jon McGinnis, Islamic Translation Series, Provo. Utah: Brigham Young University Press, 2009.

BODNAR, I. “Aristotle's Natural Philosophy”. In: E. N. Zalta (ed.). The Stanford Encyclopedia of Philosophy. Spring Edition, 2012. Accessible at http://plato.stanford. edu/archives/spr2012/entries/aristotle-natphil/. Accessed on 16 May 2014.

AL-'IRĀQİ, M. 'A. "Al-falsafa al-tabī‘īyya 'inda Ibn Sīnā”. Cairo: Dār al-Ma'ārif, 1983.

WATERLOW, S. "Nature, Change, and Agency in Aristotle's Physics". Oxford: Clarendon Press, 1982.

WOODBRIDGE, F. J. E. “Aristotle's Vision of Nature”. Edited with an Introduction by John Herman Randall Jr., with the assistance of Charles H. Kahn and Harold A. Larrabee. New York/London: Columbia University Press, 1965. 